\title{
Kepemimpinan Kepala Sekolah dalam Mengembangkan Kualitas Tenaga Pendidik di RA
}

\author{
Abdurrahman Harun ${ }^{1}$, Septiana Tanti Nurlisa ${ }^{2}$, Ulfah Nabilla Maghfi ${ }^{3}$ \\ ${ }^{1,2}$ Universitas Islam Negeri Raden Intan Lampung, Indonesia \\ ${ }^{3}$ Sekolah Tinggi Agama Islam YASBA Kalianda, Indonesia \\ abdurrahmanharun@radenintan.ac.id
}

\begin{abstract}
Abstrak
Kepemimpinan kepala sekolah wajib meningkatkan tenaga pendidik agar memiliki kemampuan atau skill pada bidang tertentu untuk mencapai sebuah tujuan pendidikan yang sesuai dengan kompetensi pendidik itu sendiri. Tujuan dari penelitian ini adalah untuk mengetahui bagaimana inplementasi kepemimpinan kepala sekolah dalam mengembangkan kualitas tenaga pendidik Raudhatul Athfaal. Metode dalam penelitian ini adalah menggunakan deskripstif kualitatif. Hasil penelitian menunjukkan bahwa penerapan yang dilakukan kepala sekolah dalam mengembangkan kualitas tenaga pendidik sudah baik dan sudah terlaksana, kepala sekolah memberikan pengembangan terhadap guru untuk mengembangkan kualitasnya dilembaga pendidikan; (1) Kepala sekolah melakukan pengembangan dengan bekerja sama dengan guru-guru untuk selalu melakukan komunikasi satu dengan yang lainnya, mengadakan kunjungan kelas, rapat rutinan dan juga melaksanakan diskusi berdasarkan individu serta melakukan penilaian, selian itu juga mendukung guru untuk mengikuti kegiatan pelatihan; (2) Sedangkan untuk kompetensi Tenaga Pendidik sudah terlaksana dengan baik meski ada beberapa pada kompetensi pedagogik yang belum terlaksana dan juga untuk penggunaan media pembelajaran memang masih sangat kurang. Kata Kunci: kepemimpinan kepala sekolah; kualitas tenaga pendidik; anak usia dini
\end{abstract}

\section{Principal Leadership in Developing the Quality of Educators in RA}

\begin{abstract}
Principal leadership is required to improve educators so that they have the ability or skills in certain fields to achieve an educational goal that is in accordance with the competence of the educators themselves. The purpose of this study was to find out how the implementation of the principal's leadership in developing the quality of Raudhatul Athfaal's teaching staff. The method in this research is using qualitative descriptive. The results showed that the implementation carried out by the principal in developing the quality of teaching staff was good and had been implemented, the principal provided development for teachers to develop their quality in educational institutions; (1) The principal develops by working with teachers to always communicate with each other, conduct class visits, regular meetings and also carry out individual-based discussions and conduct assessments, in addition to supporting teachers to take part in training activities; (2) As for the competence of Educators, it has been implemented well, although there are some pedagogic competencies that have not been implemented and also for the use of learning media, it is still very lacking.

Keywords: principal's leadership; the quality of educators; early childhood
\end{abstract}




\section{PENDAHULUAN}

Kepemimpinan kepala sekolah merupakan kemampuan untuk menggerakkan tenaga pendidik, sehingga tujuan pendidikan yang telah ditetapkan dapat tercapai secara efekif dan efisien. Wahyudi menyatakan bahwa sebuah pengetahuan, keterampilan, dan nilai-nilai dasar yang direfleksikan dalam kebiasaan berfikir dan bertindak secara konsisten yang memungkinkan seseorang menjadi kompeten atau memiliki kemapuan dalam menjalankan wewenang, tugas, dan tanggung jawab (Rosad, 2019). Dari pengertian diatas dapat dikatakan untuk menjadi kepala sekolah tidak hanya baik, jujur dan bertanggung jawab tetapi juga harus kompeten dalam menjalankan tugasnya, tidak hanya itu kepala sekolah juga memiliki wewenang bagi kemajuan sekolah yang dipimpinnya, kepala sekolah juga berhak mengeluarkan peraturan-peraturan untuk mengembangkan sekolahnya.

Selain kepala sekolah ada juga Guru yang berada dilingkungan sekolah yang mana guru-guru tersebut berada dibawah naungan kepala sekolah. Guru biasanya harus terus kreatif saat mengajar apalagi dengan guru Taman Kanak-kanak (TK), yang mana seorang guru Taman Kanak-kanak dituntut untuk terus kreatif saat mengajar. Seorang kepala sekolah memegang peran penting dalam perkembangan sekolah yang dipimpinnya. Kemampuan tersebut mempengaruhi tenaga pendidik dalam lembaga pendidikan dan bertanggung jawab atas penyelenggaraan kegiatan pendidikan, administrasi sekolah, pembinaan tenaga lainnya, dan standar pendidikan dan tenaga kependidikan. Kurang maksimalnya kepala sekolah dalam membina dan membimbing tenaga pendidik akan menyebabkan terjadinya ketidakdisiplinan tenaga pendidik, kondisi ini akan menjadi permasalahan yang kompleks ketika tidak ditindak lanjuti. Kepala sekolah harus mampu menjadi figur teladan bagi para tenaga pendidik serta peserta didik yang ada di sekolahnya dan mampu menjalankan fungsinya sebagai pemimpin (R. Dewi \& Khotimah, 2020). Kepala sekolah memikili peran dalam memimpin lembaga pendidikan bagaimana kepala sekolah mampu mengolah seluruh keseluruhan dalam lembaga untuk mencapai tujuan pendidikan termasuk tenaga pendidik dan sebagai pemimpin harus mampu memotivasi tenaga pendidik (Ulum et al., 2020).

Kepemimpinan pembelajaran sebagai upaya memimpin para guru agar mengajar lebih baik, yang pada gilirannya dapat memperbaiki prestasi belajar siswanya dan hanya berfokus pada pada guru (Daresh \& Playko, 1995). Kepemimpinan membentuk masa depan organisasi terlihat seperti dan menggerakkan organisasi menuju visi itu, sementara manajemen lebih identic dengan administrasi di Palm Beach Country melibatkan perencanaan, pengorganisasian penganggaran, kepegawaian, pengendalian, dan pemecahan masalah (Bogotch et al., 2019). Pengaturan dari pelatihan formal dari sekolah dilihat dari proses pengajaran dan pemebelajaran dan dapat dipahami tujuan instruktif. Merakit dan membangun kodrat penghuni baik selamanya sekarang dan nanti selain itu latihan edukatif dengan 
adanya pendidikan program yang merupakan inti dari pelatihan pada siswa yang saat ini mengalami degradasi (Wahyuningsih et al., 2020). Kepemimpinan adalah pemimpin yang paling kekhasan yang signifkan dan perkembangannya dalam kepemimpinan memberikan kontribusi paling besar bagi organisasi (Stippler et al., 2011). Pemimpin gaya baru atau pemimpin transformasional lebih sensitive terhadap tantangan berkelanjutan global. Mereka menyadari bahwa kemiskinan harus diatasi dengan strategi inovatif yang membangun pertumbuhan ekonomi tetapi secara berkelanjutan (Golja, 2019). Kepemimpinan merupakan upaya memimpin para guru agar menjadi lebih baik dan dapat menggerakkan organisasi menuju visi misi dengan melibatkan perencanaan, pengorganisasian penganggaran, kepegawaian, pengendalian, dan pemecahan masalah yang merupakan inti dari pelatihan pada siswa yang saat ini mengalami degradasi sehingga memberikan kontribusi paling besar.

Pentingnya penelitian ini dilakukan yaitu agar dapat mengetahui penyebab kurangnya kualitas dari tenaga pengajar di era sekarang yang dapat dilihat melalui seluruh sistem kegiatan yang di Sekolah karena berhasil atau tidaknya kegiatan belajar mengajar dipengaruhi oleh pengolahan pada sistem kegiatan belajar mengajar yang dilakukan oleh guru. Sehingga sistem kepemimpinan harus dikuasai oleh pemimpin seperti keterampilan dalam memimpin agar dapat bertindak sebagai pemimpin yang baikdan kemajuan suatu lembaga pendidikan ditentukan dengan pemberdayaan dan kepemimpinan tenaga pendidik tersebut. Penelitian ini memiliki perbedaan dengan penelitian terdahulu yaitu terletak pada variable yang dipengaruhi, dan tempat penelitian. Hal tersebut berdasarkan dari penelitian Diki Kurniawan dan Abdul Karim tahun 2019 dengan judul "Hubungan Kepemimpinan Transformasi Kepala Sekolah, Kinerja Pendidik Dan Tenaga Kependidikan”.

Dari penjelasan diatas dapat kita simpulkan bahwasannya kepala sekolah memiliki wewenang penuh untuk memanage bagaimana program sekolah harus berjalan, kepala sekolah juga yang memimpin dan mengatur serta bertanggung jawab penuh tentang administrasi sekolah dan membimbing penuh tenaga pendidik. Kepala sekolahlah yang harus menyusun strategi untuk kemajuan kualitas sebuah sekolahan tersebut yang bekerja sama dengan guru-guru. Kepala sekolah dapat melakukan perubahan dalam program pendidikan serta perencanaan dan memberi kesempatan setiap orang untuk berpartisipasi melibatkan kelompok dalam berpartisipasi dalam mengambil keputusan kepala sekolah juga dapat sebagai konsultan bagi tenaga pendidik (Nai \& Wijayanti, 2018). Kepemimpinan yang efektif dimulai dengan pengembangan visi komitmen seluruh sekolah untuk standar yang tinggi dan keberhasilan semua siswa. Kepala sekolah membantu menjelaskan visi itu dan mendapatkan semua orang lain ikut serta dengannya (Mendels, 2012).

Organisasi pendidikan akan efektif apabila organisasi yang ada di sekolah diterapkan kepemimpinan dengan satu gaya yang ditekankan kepala sekolah dalam pengolahannya sehingga gaya kepeimpinan digunakan tenaga pendidik untuk menggerakkan pelaksanaan pendidikan agar mencapai 
tujuan (Sauri et al., 2018). Sistem kepemimpinan harus dikuasai oleh pemimpin seperti halnya sebuah keterampilan dalam memimpin supaya bisa bertindak sebagai seorang pemimpin yang baik. Hal tersebut antara lain, kepala sekolah harus mengusai bagaimana cara menyusun rencana bersama, meneliti persoalan-persoalan yang muncul dilingkungan sekolah, mengajak anggota dalam berpartisipasi untuk sebuah kegiatan, serta membagi dan menyerahkan sebuah tanggung jawab.Dedi Lazwardi, Peran Kepala Sekolah Dalam Meningkatkan Profesionalisme Guru (Bandar Lampung: Universitas Nu Lampung, 2017). Kemajuan suatu lembaga pendidikan sangat ditentukan oleh bagaimana kepemimpinan dan pemberdayaan tenaga pendidiknya. Dalam hemat peneliti, lembaga pendidikan di Indonesia semakin berkembang namun kualitas atau mutu pendidik belum dimaksimalkan, sehingga beberapa sekolah harus mengalami penurunan prestasi sekolah dan bahkan berdampak kepada penurunan jumlah peserta didik. Tenaga pendidik dan objek yang dididik kurang diperhatikan, terutama dalam pemenuhan standar layanan minimal pendidikan.

Kepemimpinan meliputi kemampuan seseorang dalam mengatakan sesuatu terhadap orang lain yang saling berhubungan, seorang pemimpin harus dapat mengkomunikasikan semua aktivitas manajerial untuk memgembangkan kualitas standar pendidik dan tenaga pendidik serta seluruh jajarannya (Djafri, 2015). Kualitas seorang pendidik diukur dari standar keilmuan akademik yang pendidik miliki, keterampilan, kecakapan yang bisa diterapkan dalam kegiatan belajar mengajar. Jumlah kesiapan pendidik atau guru yang berkualitas dalam proses penyelenggaraan pendidikan perlu diupayakan melalui berbagai program seperti memberikannya fasilitas untuk melakukan studi lanjut, mengikuti pelatihan dan kegiatan lain atau supervisi kepala sekolah yang mampu mengembangkan kompetensi professional (Alawiyah, 2013; Hakim, 2017).

Menurut Undang-undang Guru dan Dosen, kompetensi yang harus dimiliki oleh seorang guru adalah :

1. Kompetensi Pedagogik, yaitu kemampuan mengelola pembelajaran peserta didik

2. Kompetensi Kepribadian, yaitu kemampuan kepribadian yang percaya diri, berakhlak mulia, bijaksana, dan berwibawa serta dapat menjadi teladan bagi peserta didik

3. Kompetensi sosial, yaitu kemampuan guru untuk berkomunikasi dan berinteraksi secara efektif dan efisien dengan peserta didik, sesama guru, orang tua/wali peserta didik, dan masyarakat sekitar.

4. Kompetensi Profesional, yaitu kemampuan penguasaan materi pembelajaran secara luas dan mendalam (Maralih, 2014).

Menurut Pandangan Bennis yang dikutip oleh Hersey dan Blanchard yang mengidentifikasikan empat sifat yang harus dimiliki kepala sekolah dalam mengembangkan kualitas guru maupun tenaga pendidik di anataranya; (a) Kemampuan mengkomunikasikan tujuan atau arah dari lembaga pendidikan yang dapat menarik perhatian dari para tenaga pendidik, (b) kemampuan menciptakan dan mengkomunikasikan makna dan tujuan tersebut dengan jelas dan dapat dipahami oleh tenaga pendidik, 
c) kemampuan agar dapat dipercaya dan konsisten sehingga tenaga pendidik akan memperhatikannya,

d) memiliki keterampilan dari diri sendiri untuk meningkatkan motivasi terhadap kemajuan tenaga pendidik (Djafri, 2015).

\section{METODE PENELITIAN}

Desain penelitian yang digunakan dalam penelitian mengguana singel case design yaitu metode yang digunakan untuk menggambarkan atau mendeskripsikan secara utuh dan mendalam sesuai fakta dan sesuai fenomena yang terjadi di masyarakat yang menjadi subyek penelitian sehingga tergambarkan sifat, karakter, model dan cirri dari fenomena tersebut (John W. Creswell, 2017). Data Sekunder yang penulis dapat dalam penelitian ini adalah hasil dokumentasi dan data lainnya di RA Al-Ikhlas Pemetung Basuki OKU Timur. Dalam penelitian ini penulis memilih untuk melaksanakan penelitian ini di RA AlIkhlas Pemetung Basuki, karena peneliti tertarik untuk melihat bagaimana implementasi kepala sekolah dalam mengembangkan kualitas tenaga pendidik di RA Al-Ikhlas Pemetung Basuki. Penelitian ini dilakukan pada tanggal 18 Juni 2021 sampai dengan selesai. Jumlah sampel pada penelitian ini yaitu berjumlah 5 sampel 1 kepala sekolah dan 4 tenaga pendidik yang keseluruhannya menempuh pendidikan Strata satu (S1). Data yang diperlukan dalam penelitian ini diperoleh dengan menggunakan teknik pengumpulan data menggunakan observasi, wawancara, dokumentasi. Keabsahan data menggunakan Triangulasi data.

\section{HASIL DAN PEMBAHASAN}

\section{A. Hasil}

Kepala sekolah tentu melakukan upaya dalam mengembangkan kualitas tenaga pendidik sebagai seorang yang memimpin sekolah, kepala sekolah harus memiliki strategi tersendiri dalam memberikan penguatan terhadap kualitas guru. Adapun beberapa penguatan yang dilakukan kepala sekolah di RA Al-Ikhlas Pemetung Basuki; (1) Kepala Sekolah sebagai Manager, Peran seorang manajer itu sendiri sangat penting di lembaga pendidikan, kepala sekolah harus memiliki strategi khusus dalam mengembangkan kualitas tenaga pendidik melalui kerjasama yang baik dan mendorong ataupun mengajak para guru untuk terlibat dalam hal apapun dalam semua kegiatan serta memberikan sebuah kesempatan kepada guru untuk mengembangkan profesinya. Kepala sekolah RA Al-Ikhlas dalam hal ini adalah untuk mengembangkan kualitas tenaga pendidik yang ada di RA Al-Ikhlas itu sendiri beliau melakukan beberapa cara yaitu dengan menyarankan serta menghimbau kepada guru untuk saling komunikasi dan saling bekerja sama baik antara kelas satu dengan yang lainnya. 
Kepala sekolah melakukan hal tersebut untuk mengantisipasi adanya miss komunikasi dan supaya untuk mengantisipasi adanya kesulitan-kesulitan yang ada agar dapat dikerjakan bersamasama untuk saling memberi masukan ataupun saling bertukar pikiran dalam melaksanakan tugasnya serta tanggung jawabnya sebagai seorang guru; (2) Pengembangan yang dilakukan di Sekolah, Proses pengembangan kepala sekolah terhadap para pendidik itu terdapat dua bagian yang diantaranya pengembangan yang dilakuukan didalam sekolah dan juga pengembangan yang dilakukan diluar sekolah antara lain; (3) Percakapan Individu, Kepala sekolah melakukan percakapan individu dengan para guru satu-persatu, hal itu dilakukan kepala sekolah secara individu supaya kepala sekolah bisa memahami karakter setiap guru, masalah yang dialami setiap guru dan bahkan keluhan dari setiap guru lebih detail dan jelas; (4) Rapat Rutinan, Pengembangan yang dilakukan selanjutnya yaitu kepala sekolah RA Al-Ikhlas mengadakan Rapat Rutinan dengan seluruh guru yang ada di RA Al-Ikhlas Pemetung Basuki, dilakukannya hal tersebut guna untuk mengembangkan kualitas dari para guru yang ada di RA Al-Ikhlas Pemetung Basuki. Rapat ini biasanya diadakan setiap satu bulan sekali untuk melihat perkembangannya selama sebulan apakah ada kesulitan dan untuk mengevaluasi para guru; (5) Kunjungan Kelas, Kunjungan kelas ini yaitu yang dilakukan kepala sekolah disetiap kelas pada proses belajar mengajar. Dengan tujuan untuk melihat kemampuan dari guru serta membantu guru dalam menghadapi kesulitan saat proses belajar mengajar. Kegiatan kunjungan kelas ini juga dilakukan kepala sekolah RA Al-Ikhlas pemetung basuki; (6) Penilaian, Penilaian merupakan salah satu cara yang dilakukan kepala sekolah untuk mengembangkan kualitas tenaga pendidik.

Penilaian ini dilaksanakan untuk menganalisis tugas tenaga pendidik yang dengan tujuan mengembangkan kualitas tenaga pendidik itu sendiri. Kepala sekolah mengadakan pengembangan melalui penilaian terhadap guru dengan mengacu pada kompetensi guru. Melihat bahwa kompetensi guru memang harus dikuasai apabila seseorang ingin menjadi tenaga pendidik. Penilaian yang dilakukan kepala sekolah biasanya meliputi kompetensi guru diantaranya kompetensi pedagogic, sosial, kepribadian, dan professional. Melalui penilaian ini dapat mempermudah kepala sekolah dalam mengetahui perkembangan kualitas guru. Tentunya kepala sekolah memiliki tolok ukur tersendiri dalam melakukan penilaiannya seperti halnya; rencana pelaksanaan pembelajaran harian (RPPH), penggunaan media pembelajaran, kesiapan guru dalam menyiapkan perlengkapan pembelajaran, serta pengelolaan didalam kelas. Selain itu kepala sekolah juga melakukan penilaian terhadap kompetensi sosial dan juga kepribadian yang dimiliki oleh guru. Selain monitoring yang dilakukan kepala sekolah di dalam kelas, kepala sekolah juga memberikan kesempatan kepada guru untuk mengembangkan pedagogic yang dimiliki. Adapunpengembangan tidak hanya dilakukan di dalam sekolah saja tetapi juga dilakukan di luar sekolah. 
Hal yang dilakukan kepala sekolah RA Al-Ikhlas dalam pengembangan luar sekolah di antaranya; (1) Pelatihan, Guru yang berkualitas adalah guru yang memiliki banyak kemampuan terkhusus dalam hal belajar mengajar. Dengan hal itu guru perlu mengembangkan kualitasnya dengan mengasah kemampuannya. Dalam hal mengembangkan kualitas tenaga pendidik kepala sekolah mengikut sertakan guru-guru dalam kegiatan seperti halnya pelatihan-pelatihan, seperti; pelatihan workshop, kurikulum, kegiatan yang berkaitan dengan kompetensi guru serta pelatihan tentang perangkat pembelajaran.

Pelatihan adalah suatu kegiatan yang dilakukan oleh guru supaya guru dapat mengubah perilaku serta kegiatan belajar mengajar di dalam kelas. Pendapat diatas didukung dengan pernyataan yang disampaikan oleh guru-guru yang ada si RA Al-Ikhlas yang diungkapkan pada paparan data. Oleh karena itu hal ini menyebutkan bahwa kepala sekolah selalu memberikan kesempatan dan dukungan kepada guru-guru untuk selalu belajar dengan pengetahuan-pengetahuan yang baru dan meningkatkan keterampilannya dengan mengikuti pelatihan; (2) Faktor pendukung, Sebagai kepala sekolah banyak sekali faktor-faktor yang mempengaruhinya dalam melaksanakan tugasnya, termasuk juga faktor pendukung. Dalam hal ini kepala sekolah RA Al-Ikhlas faktor yang mendukungnya dalah sarana dan prasarana meskipun belum terlalu memadai setidaknya sannga membantu dalam menjalankan tugasnya; (3) Faktor Penghambat, Dalam mengembangkan kualitas dari tenaga pendidik tentunya tidak selalu berjalan dengan baik terkadang juga memiliki hambatan dalam mengembangkan kualitas tenaga pendidik diantaranya kurangnya pemahaman atau pemakaian terhadap teknologi dan juga kurangnya penggunaan media pembelajaran.

\section{B. Pembahasan}

Fasli Jalal dan Dedi Supriyadi mengutip laporan Bank Dunia yang bertajuk Education in Indonesia: From Crisis to Recovery tanggal 23 Septeber 1998 antara lain menyorot persoalan guru dan tenaga kependidikan, bahwa guru merupakan sentral dari upaya peningkatan mutu pendidikan, karena itu setiap upaya untuk membenahi pendidikan akan dan harus memelihara penataan terhadap guru (I. Dewi \& Suryana, 2020). Lebih lanjut dijelaskannya bahwa pada prinsipnya ada tiga isu dominan tentang guru yang disorot dalam laporan tersebut, yaitu "mutu guru yang berkaitan dengan pendidikan prajabatan dan seleksi, insentif yang diperolehnya, dan penyebaran guru yang tidak merata. Tantangan dan strategi ke depan adalah bagaimana meningkatkan mutu guru (baik melalui pendidikan prajabatan maupun melalui pendidikan dalam jabatan), membuat mereka lebih terlatih, tingkat kesejahteraan/insentif guru lebih baik, sehingga membuat profesi keguruan lebih menarik dan kompetitif sejalan dengan tuntutan tugasnya, dan penyebaran guru lebih merata.

Dari beberapa pendapat diatas dapat kita lihat bahwa standar pendidikan dan Tenaga Kependidikan adalah capaian pendidikan dengan kualifikasi kemampuan untuk tujuan pendidikan 
itu sendiri, kualifikasi pendidikan juga termasuk kualifikasi akademik yang harus dimiliki oleh seorang guru baik guru mendasar menengah maupun anak usia dini, kualifikasi akademik yang dimaksud adalah tingkat pendidikan minimal yang harus dimiliki oleh seorang pendidik dan tenaga kependidikan dengan dibuktikannya adanya sertifikat jenjang strata maupun dengan sertifikat melalui pelatihan-pelatihan.

Kepemimpinan merupakan cara seseorang memimpin bawahannya dengan mempengaruhi perilaku agar mau bekerja sama dan bekerja secara produktif untuk mencapai tujuan organisasi (Hasibuan, 2014). Kepemimpinan pembelajaran dan strategi komunikasi sesuai dengan kepentingan dan kebutuhan agar berjalan secara otomatis sehingga menjadi suatu keharusan yang harus dilakukan untuk mewujudkan pembelajaran yang berkualitas (Suyahman, 1967). Pemimpin pendidikan tingkat satuan pendidikan yang bertanggung jawab seluruh kegiatan sekolah adalah kepala sekolah yang merupakan kedudukannya sangat penting dalam lingkungan sekolah karena langsung berhubungan dan dekat dengan pelaksanaan program pendidikan setiap harinya (Ngalim Purwanto, 2005).

Temuan penelitian yang ditemukan oleh Peneliti di RA Al-Ikhlas pemetung basuki yaitu dalam mengembangkan kualitas tenaga pendidik dapat dilihat dari kepemimpinan kepala sekolah dengan pengembangan yang dilakukan oleh kepala sekolah baik dari pengembangan sekolah maupun luar sekolah. Kualitas tenaga pendidik sudah cukup baik yang dilakukan kepala sekolah melalui pengembangan, namun masih sangat kurang dari segi ketenaga pendidik sehingga masih diharuskan untuk belajar lagi. Serta masih kurang dalam penguasaan media pembelajaran guru dan masih terpaku pada buku panduan dalam penguasaan media pembelajaran. Penelitian dilakukan untuk kompetensi professional yang sudah terlaksana namun pada kompentensi pedagogic pendidik masih ada beberapa yang kurang dengan melihat dari kompetensi lain yang sudah terlaksana.

Guru sebagai pendidik professional karena sebagian tanggung jawab pendidikan anak dilaksanakan oleh guru sehingga tidak semua orang dapat menjabat sebagai seorang guru ketika orang tua menyerahkan anaknya disekolah orang tua tidak mungkin mempercayai anaknya kesembarang guru (Drajat et al., 2014). sebagai guru berusaha untuk menyajikan materi, dan paham mengenai kebutuhan yang dibutuhkan siswa dalam belajar serta memanfaatkan lingkungan sekolah sebagai sumber belajar (Wahid et al., 2020). dalam meningkatkan kinerja guru berpengaruh pada pola kepemimpinan kepala sekolah karena pemimpin harus memiliki keterampilan dalam mendorong, mempengaruhi, mengarahkan, menggerakkan dan membimbing orang lain yang berhubungan dengan pelaksanaan dan pengembangan pendidikan dan pengajaran ataupun pelatihan agar dapat berjalan dengan lancar sehingga dapat mencapai tujuan (Baihaqi, 2015). 
Guru adalah pendidik. Guru adalah seorang dengan pekerjaan atau profesinya mengajar. Guru merupakan sosok yang mengemban tugas mengajar, mendidik dan membimbing.(Fadjar, 2011) Di dalam Rancangan Peraturan Pemerintah (RPP) BAB XII, Tahun 2005 Pasal 139, Pasal 1 dinyatakan bahwa pendidik mencakup guru, dosen, konselor, pamong belajar, pamong widyaiswara, tutor, instruktur, fasilitator, pelatih, dan sebutan lain dari profesi yang berfungsi sebagai agen pembelajaran peserta didik. Di dalam Peraturan Pemerintahan Nomor 19 Tahun 2005 Tentang Standar Nasional Pendidikan, Bab VI, Pasal 28 dinyatakan bahwa Kompetensi sebagai agen pembelajaran pada jenjang pendidikan dasar dan menengah serta anak usia dini meliputi, kompetensi : pedagogik, kepribadian, profesinal, dan sosial. Tenaga kependidikan dinyatakan dalam pasal 140 ayat 1 (RPP, Bab XII/2005) sebagai berikut. Tenaga kependidikan mencakup pimpinan satuan pendidikan, penilik satuan pendidikan nonformal, pengawas satuan pendidikan formal, tenaga perpustakaan, tenaga laboraturium, teknisi sumber belajar, tenaga lapangan pendidikan, tenaga administrasi, psikolog, pekerja sosial, terapis, tenaga kebersihan sekolah, dan sebutan lain untuk petugas sejenis yang bekerja pada satuan Pendidikan (Bachtiar, 2016). Tenaga pendidik diharapkan dapat menguasai bidang masing-masing sehingga diperlukannya peningkatan kompetensi selain itu peran pendidik lebih ditekankan pada fasilitator yang memfasilitasi atau membantu siswa dalam belajar agar dapat membangun pengetahuan siswa maka diperlukannya proses pembelajaran yang demokratis (Bachtiar, 2016)

Secara garis besar ada dua kualifikasi yang dipersyaratkan yaitu kualifikasi akademik dan non akademik. Sebagaimana ditegaskan dalam pasal 28 bahwa pendidik dan tenaga kependidikan harus memiliki kualifikasi akademik dan kompetensi sebagai agen pembelajaran, sehat jasmani dan rohani, serta memiliki kemampuan untuk mewujudkan tujuan pendidikan nasional. Kualifikasi akademik yang dimaksudkan adalah tingkat pendidikan minimal yang harus dipenuhi oleh seorang pendidik dan tenaga kependidikan yang dibuktikan dengan ijazah dan/atau sertifikat keahlian yang relevan sesuai ketentuan perundang-undangan yang berlaku. Kompetensi sebagai agen pembelajaran pada jenjang pendidikan dasar dan menengah serta pendidikan anak usia dini meliputi: Kompetensi Pedagogik, Kompetensi Kepribadian, Kompetensi Profesional, dan Kompetensi Sosial.

\section{SIMPULAN DAN SARAN}

Berdasarkan hasil penelitian yang penulis lakukan terhadap "Implementasi Kepemimpinan Kepala Sekolah dalam mengambangkan Kualitas Tenaga Pendidik" dapat disimpulkan bahwa Penerapan yang dilakukan kepala sekolah dalam mengembangkan kualitas tenaga pendidik di RA AlIkhlas Pemetung Basuki sudah baik dan sudah terlaksana, kepala sekolah memberikan pengembangan terhadap guru untuk mengembangkan kualitasnya dilembaga pendidikan. Peran sebagai manajer 
merupakan bentuk peran yang dilakukan kepala sekolah dalam mengembangkan kualitas tenaga pendidiknya. Selain itu kepala sekolah juga melaksanakan pengembangan didalam kelas dan juga diluar kelas. Untuk kompetensi dari tenaga pendidik itu sendiri sudah terpenuhi dengan baik tetapi ada beberapa pada bagian kompetensi

Bentuk peran sebagai manajer tentunya kepala sekolah memberikan wawasan dengan mendukung tenaga pendidik untuk melanjutkan pendidikannya baik yang belum selesai atau yang sudah selesai dan ingin melanjutkan kejenjang yang lebih tinggi lagi. Kepala sekolah juga melakukan pengembangan dengan bekerja sama dengan guru-guru untuk selalu melakukan komunikasi satu dengan yang lainnya, mengadakan kunjungan kelas, rapat rutinan dan juga melaksanakan diskusi berdasarkan individu serta melakukan penilaian. Selain pengembangan didalam sekolah kepala sekolah juga melakukan pengembangan diluar sekolah diantaranya mendukung guru untuk mengikuti kegiatan pelatihan. Faktor pendukung yang dialami kepala sekolah untuk mengembangkan kualitas tenaga pendidik diantaranya semangat dan rasa antusias dari diri guru itu sendiri serta terpenuhinya sarana dan prasarana. Terlebih lagi ada faktor penghambatnya yaitu dari segi kurang menguasai teknologi dan juga kurangnya penggunaan media pembelajaran. Sedangkan untuk kompetensi Tenaga Pendidik sudah terlaksana dengan baik tetapi untuk penggunaan media pembelajaran memang masih sangat kurang.

\section{DAFTAR PUSTAKA}

Alawiyah, F. (2013). Peran Guru dalam Kurikulum 2013. Aspirasi, 4(1), 65-74. http://jurnal.dpr.go.id/index.php/aspirasi/article/view/480

Bachtiar, M. Y. (2016). Pendidik Dan Tenaga Kependidikan. Publikasi Pendidikan, 6(3). https://doi.org/10.26858/publikan.v6i3.2275

Baihaqi, M. I. (2015). Pengaruh Gaya Kepemimpinan Kepala Sekolah Dan Motivasi Kerja Terhadap Kinerja Guru Di Ma Ma'Arif Selorejo Blitar. Konstruktivisme: Jurnal Pendidikan \& Pembelajaran, 7(2), 97-106. https://doi.org/10.30957/konstruk.v7i2.14

Bogotch, I., Bauer, S., \& Su-Keene, E. (2019). New beginnings, repeated: The continuing search for educational leadership. Research in Educational Administration and Leadership, 4(1), 110-146. https://doi.org/10.30828/real/2019.1.5

Daresh, J. C., \& Playko, M. A. (1995). Alternative Career Formation Perspectives: Lessons for Educational Leadership from Law, Medicine, and Training for the Priesthood. Lmi, 1-54.

Dewi, I., \& Suryana, D. (2020). Analisis Evaluasi Kinerja Pendidik di PAUD Al-Azhar Bukittinggi. Obsesi, 4(2). https://doi.org/10.31004/obsesi.v4i2.465

Dewi, R., \& Khotimah, S. H. (2020). Pengaruh Profesionalisme Dan Disiplin Kerja Guru. ELEMENTARY Islamic Teacher Journal, 8(2), 279-294.

Djafri, N. (2015). Manajemen dan Kepemimpinan Kepala Sekolah (p. 19).

Drajat, M., Ridwan Effendi, M., \& Heri Gunawan. (2014). Etika Profesi Guru. Alfabeta.

Fadjar, A. M. (2011). Pengembangan Profesi Guru. UIN Maliki Press.

Golja, T. (2019). Impacts of Transformational Leadership on Effective Implementation of CSR

$2.0-$ The Case of Croatia. E-Journal of Tourism, 6(1), 1. 
https://doi.org/10.24922/eot.v6i1.47473

Hakim, L. (2017). Analisis Perbedaan Antara Kurikulum. Jurnal Ilmiah Didaktika, 17(2), 280292. https://doi.org/10.22373/jid.v16i1.590.5

Hasibuan, M. (2014). Manajemen Sumber Daya Manusia. Bumi Aksara.

John W. Creswell, C. N. P. (2017). Qualitative Inquiry and Research Design (International Student Edition): Choosing Among Five Approaches. SAGE Publications.

Lazwardi, D. (2017). Peran Kepala Sekolah dalam Meningkatkan Profesionalisme Guru. Universitas NU Lampung.

Maralih. (2014). Peranan Supervisi dalam Peningkatan Kualitas Penidididkan. Jurnal Pendidikan.

Mendels, P. (2012). Ed072153. 33(1), 54-57.

Nai, H., \& Wijayanti, W. (2018). Pelaksanaan tugas dan fungsi kepala sekolah pendidikan menengah negeri. Jurnal Akuntabilitas Manajemen Pendidikan, 6(2), 183. https://doi.org/10.21831/amp.v6i2.10182

Ngalim Purwanto. (2005). Administrasi dan supervisi pendidikan. Remaja Rosdakarya. Rosad, A. M. (2019). Implementasi Pendidikan Karakter Melalui Managemen Sekolah.

Tarbawi: Jurnal Keilmuan Manajemen Pendidikan, 5(02), 173. https://doi.org/10.32678/tarbawi.v5i02.2074

Sauri, A. S., Widyasari, W., \& Sesrita, A. (2018). Pengaruh Kepemimpinan Kepala Sekolah $\begin{array}{lllll}\text { Terhadap Kinerja } & \text { Guru. }\end{array}$ https://doi.org/10.30997/jtm.v2i1.1160

Stippler, M., Moore, S., Rosenthal, S., \& Tina Doerffer. (2011). Leadership. Approaches Development - Trends. Verlag Bertelsmann Stiftung.

Suyahman. (1967). Implementasi Strategi Komunikasi Pembelajaran Dan Kepemimpinan Pembelajaran Sebagai Upaya Menciptakan Pembelajaran Yang Berkualitas. Angewandte Chemie International Edition, 6(11), 951-952., 13(April), 15-38.

Ulum, M. B., Sarwoko, E., \& Yuniarinto, A. (2020). Kepemimpinan Kepala Sekolah Dan Kinerja Guru: Peran Mediasi Motivasi Kerja. Jurnal Administrasi Dan Manajemen Pendidikan, 3(4), 299-307. https://doi.org/10.17977/um027v3i42020p299

Wahid, F. S., Purnomo, M. A., \& Ulya, S. M. (2020). Analisis Peran Guru Dalam Pemanfaatan Lingkungan Sekolah Terhadap Kreativitas Belajar Siswa. Jurnal Ilmiah Kontektual, 2(01), 38-42. https://doi.org/10.46772/kontekstual.v2i01.247

Wahyuningsih, S., Abbas, E. W., \& Mutiani, M. (2020). Implementation of Leadership Value of Rudy Resnawan as a Learning Resources on Social Studies. The Innovation of Social Studies Journal, 1(2), 169. https://doi.org/10.20527/iis.v1i2.2094 